\title{
Chronic treatment with zinc and antidepressants induces enhancement of presynaptic/extracellular zinc concentration in the rat prefrontal cortex
}

\author{
Magdalena Sowa-Kućma · Magdalena Kowalska • Marek Szlósarczyk • \\ Krystyna Gołembiowska • Włodzimierz Opoka • Bogusław Baś • \\ Andrzej Pilc · Gabriel Nowak
}

Received: 20 November 2009/ Accepted: 24 May 2010/Published online: 9 June 2010

(c) The Author(s) 2010. This article is published with open access at Springerlink.com

\begin{abstract}
Zinc exhibits antidepressant-like activity in preclinical tests/models. Moreover, zinc homeostasis is implicated in the pathophysiology of affective disorders. The aim of the present study was to examine the effect of chronic zinc, citalopram and imipramine intraperitoneal administration on the presynaptic and extracellular zinc concentration in the rat prefrontal cortex and hippocampus. We used two methods: zinc-selenium histochemistry (which images the pool of presynaptic-vesicle zinc) and anodic stripping voltammetry (ASV) for zinc determination in microdialysate (which assays the extracellular zinc concentration). We report that chronic $(14 \times)$ zinc (hydroaspartate, 10 and $65 \mathrm{mg} / \mathrm{kg})$ and citalopram $(20 \mathrm{mg} / \mathrm{kg})$ administration increased the pool of presynaptic zinc (by 34,50 and $37 \%$, respectively) in the rat prefrontal cortex. The $21 \%$ increase induced by imipramine $(20 \mathrm{mg} / \mathrm{kg})$ was marginally significant. Likewise, zinc (hydroaspartate, $65 \mathrm{mg} / \mathrm{kg}$ ), citalopram and imipramine increased the extracellular zinc (although
\end{abstract}

M. Sowa-Kućma · M. Kowalska · K. Gołembiowska · A. Pilc · G. Nowak $(\bowtie)$

Institute of Pharmacology, Polish Academy of Sciences

and Center of Excellence in Neuropsychopharmacology, Smętna 12, 31-343 Kraków, Poland

e-mail: nowak@if-pan.krakow.pl

M. Szlósarczyk · W. Opoka · G. Nowak

Faculty of Pharmacy, Jagiellonian University Collegium

Medicum, Medyczna 9, 30-688 Kraków, Poland

A. Pilc

Faculty of Health Sciences, Jagiellonian University Collegium Medicum, Michałowskiego 20, 31-126 Kraków, Poland

B. Baś

Faculty of Material Science and Ceramics, AGH University of Science and Technology, Mickiewicza 30, 30-059 Kraków, Poland with a different pattern: time point, area under the curve and/ or basal level) in this brain region. Furthermore, zinc induced an increase in presynaptic (by 65\%) and extracellular zinc (by 90\%) in the hippocampus, while both citalopram and imipramine did not. These results indicate that all of the treatments increase presynaptic/extracellular zinc concentrations in the rat prefrontal cortex, which may then contribute to their antidepressant mechanisms. Alterations induced by zinc (but not antidepressants) administration in the hippocampus may be related to specific zinc mechanisms. All the data (previous and present) on the effect of antidepressant treatments on the presynaptic/extracellular zinc concentrations suggest the involvement of this biometal presynaptic/synaptic homeostasis in the antidepressant mechanism(s).

Keywords Zinc $\cdot$ Antidepressants ·

Zinc-selenium histochemistry · Microdialysis .

Stripping voltammetry

\section{Introduction}

Zinc is the second most abundant trace metal (after iron) in mammalian tissues, and it is an essential element for growth, development, DNA synthesis, immunity and other important cellular processes (Takeda 2000). Besides, this trace element acts as a cellular signaling molecule and is present in many regions of the mammalian central nervous system (CNS), particularly in the cerebral cortex and hippocampus (Frederickson et al. 2005).

Less than $5 \%$ of the total amount of zinc in the brain is located inside presynaptic vesicles in zinc-containing neuron terminals. This pool of zinc can be selectively stained by several histochemical procedures that make it 
then available to histological and histochemical studies. The majority of vesicular zinc is found within glutamatergic neurons, although not all of the glutamatergic neurons contain zinc (Frederickson and Bush 2001; Slomianka 1992). Presynaptic zinc is released in an activity-dependent manner, diffuses across the synaptic cleft and proceeds to have some effect on the postsynaptic neuron. Zinc is an important modulator of inhibitory and excitatory synaptic transmissions. It has been shown to modulate the action of multiple receptors and channels, enhancing AMPA (GluR3 subunit) and ATP-sensitive potassium (KATP) channel activity and inhibiting NMDA, GABA $\mathrm{A}_{\mathrm{A}}$ and voltagedependent channel responses (Bancila et al. 2004; Harrison and Gibbons 1994; Smart et al. 1994).

It has been assumed that alteration in zinc homeostasis is associated with growth disturbances in children, immune deficiency and behavioral disturbances, such as taste and smell acuity, dysphoria, anorexia, impaired learning and cognitive function, besides some neurological disorders (e.g. epilepsy, Alzheimer's disease) (Frederickson et al. 2005; Takeda et al. 2003). Recent experimental and clinical observations have suggested that zinc is involved in the psychopathology and therapy of depression (see Szewczyk et al. 2008 for review). Several reports have revealed lower serum zinc concentration in patients suffering from depression (Maes et al. 1994, 1997, 1999; Nowak et al. 1999), which was then normalized after successful antidepressant therapy (Maes et al. 1999; McLoughlin and Hodge 1990; Schlegel-Zawadzka et al. 2000). Additionally, our clinical study indicates the beneficial role of zinc supplementation on antidepressant therapy in unipolar depression (Nowak et al. 2003a), especially in drugresistant patients (Siwek et al. 2009).

Pre-clinical studies have shown that acute and repeated zinc administration produces an antidepressant-like effect in animal behavioral tests (tail suspension test, forced swimming test; Kroczka et al. 2000, 2001; Rosa et al. 2003) and models of depression (chronic, mild and unpredictable stress, olfactory bulbectomy; Cieslik et al. 2007; Cunha et al. 2008; Nowak et al. 2003c; Sowa-Kućma et al. 2008). Moreover, the co-administration of zinc and antidepressants at ineffective doses exhibits an antidepressant-like effect (Kroczka et al. 2001; Szewczyk et al. 2002, 2009; Cieslik et al. 2007). On the other hand, zinc deficiency induces depressive behavior and neurochemical changes in rodents (Corniola et al. 2008; Tassabehji et al. 2008; Whittle et al. 2009).

All these data suggest possible antidepressant/adjunct zinc activity in human depression. However, the mechanism of zinc antidepressant action, at the cellular level, is not clearly understood.

Since the mechanism of antidepressants is related to adaptive changes induced by chronic treatment, in the present study, we investigated the influence of chronic zinc, imipramine and citalopram treatment on the presynaptic (vesicular) and extracellular (synaptic) zinc level in the rat prefrontal cortex and hippocampus. These brain regions were chosen because preclinical and clinical studies have revealed their importance in depression [e.g. (Rajkowska and Miguel-Hidalgo 2007; Drevets et al. 2008; Lorenzetti et al. 2009)]. We used the zinc-selenium method (which visualizes the vesicular zinc) and anodic stripping voltammetric zinc detection in brain microdialysates (which assays extracellular zinc). The dose/treatment schedule of zinc was previously examined and was effective in behavioral and biochemical experiments (Kroczka et al. 2000, 2001; Nowak et al. 2003c, 2004; Rosa et al. 2003; Sowa-Kućma et al. 2008).

\section{Materials and methods}

\section{Animals}

The experiments were carried out on male Wistar rats (280-320 g). The animals were kept under a 12:12 h lightdark cycle with free access to food and water. The experimental group consisted of four to six animals. Zinc hydroaspartate (Farmapol, Poznan, Poland) at a dose of $10 \mathrm{mg} / \mathrm{kg}(1.8 \mathrm{mg}$ of $\mathrm{zinc} / \mathrm{kg})$ or $65 \mathrm{mg} / \mathrm{kg}(11.3 \mathrm{mg}$ of zinc $/ \mathrm{kg}$ ), imipramine (Sigma, Germany) at a dose of $20 \mathrm{mg} / \mathrm{kg}$ and citalopram (Lundbeck, Denmark) at a dose of $20 \mathrm{mg} / \mathrm{kg}$ or vehicle $(0.9 \%$ sodium chloride, control rats) were administered intraperitoneally (i.p.), once daily for 14 days. All procedures were conducted in compliance with the National Institutes of Health Animal Care and Use Committee guidelines, and were approved by the Ethics Committee of the Institute of Pharmacology, PAS, Krakow.

\section{Synaptic zinc visualization}

For histochemical detection of presynaptic (histochemically reactive, vesicular) zinc, we applied the zincselenium method (Timm's staining) described by Danscher (1982) with modifications described by Czupryn and Skangiel-Kramska (2003). In this method, the presynaptic pool of zinc is visualized with silver salt enhancement after the application of exogenous selenite. Sodium selenite was administered intraperitoneally at a dose of $15 \mathrm{mg} / \mathrm{kg}, 24 \mathrm{~h}$ after the last treatment of zinc hydroaspartate, imipramine and citalopram. The rats were deeply anesthetized with vetbutal $(0.7 \mathrm{mg} / \mathrm{kg}) 1 \mathrm{~h}$ after sodium selenite administration and perfused transcardially with $0.1 \mathrm{M}$ Sörensen's buffer ( $\mathrm{pH}$ 7.4) for $7 \mathrm{~min}$. After perfusion the brains were quickly removed, frozen in cold heptane $\left(-70^{\circ} \mathrm{C}\right)$. Thick 
coronal sections $(20 \mu \mathrm{m})$ were cut in a cryostat, thaw-mounted onto gelatin/chrome-alum-coated glass slides and stored at $-70^{\circ} \mathrm{C}$ until histochemical processing.

The brain sections were allowed to dry at room temperature, hydrated, fixed in a descending series of ethanol ( 15 min in $95 \%, 2$ min both in 70 and 50\%), dipped in water and finally in $0.5 \%$ gelatin solution. Then the slides were immersed in fresh developing solution $(60 \mathrm{ml}$ of $40 \%$

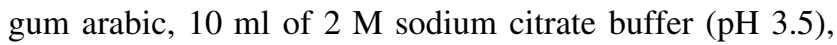
$15 \mathrm{ml}$ of $0.5 \mathrm{M}$ hydroquinone and $15 \mathrm{ml}$ of $37 \mathrm{mM}$ silver lactate) and incubated in a dark room at $26^{\circ} \mathrm{C}$ for $140 \mathrm{~min}$. The developing solution was then poured off, and the gum arabic was removed from the slices by washing in running tap water $\left(40^{\circ} \mathrm{C}\right)$ for $20 \mathrm{~min}$, followed by rinsing twice for 2 min in deionized water. It was postfixed in $70 \%$ ethanol for $30 \mathrm{~min}$ and dehydrated in an ascending ethanol series. Finally, the sections were cleared with xylene and coverslipped using Permount.

Analysis of sections and semiquantitative measurements

The coronal sections of the dorsal hippocampus and frontal cortex were examined under a light microscope (Optiphot, Nikon). The optical density measurements were obtained using an image analysis system (MCID M4; Imaging Research Inc. Ont., Canada). The staining intensity was examined in 15-20 sections of each rat at levels -3.14 to -3.8 (in the hippocampus) and 3.5-2.6 (in the prefrontal cortex) in relation to bregma, according to the Paxinos and Watson (1998) stereotaxic coordinates. Both the right and left frontal cortices and hippocampi were analyzed. The stratum moleculare fascia dentate of the DG and the corpus callosum (the regions consistently showing low staining levels) were taken as reference structures in each section in the hippocampus and prefrontal cortex, respectively. The relative optical density (ROD) values for each structure was determined by estimation of mean values divided by the ROD obtained in the reference area.

In vivo microdialysis

One day before the experiment, the rats were anesthetized with ketamine $(75 \mathrm{mg} / \mathrm{kg}$ i.m.) and xylazine $(10 \mathrm{mg} / \mathrm{kg}$ i.m.) and placed into a stereotaxic apparatus (David Kopf Instruments, Tujunga, CA, USA). The scalp was retracted and holes drilled through the skull for insertion of the vertical microdialysis probe into the prefrontal cortex ( $2.7 \mathrm{~mm}$ anterior from the bregma, $0.6 \mathrm{~mm}$ lateral from the sagittal suture and $-5.5 \mathrm{~mm}$ ventral from the dural surface) or hippocampus $(-3.8 \mathrm{~mm}$ anterior from the bregma, $3.4 \mathrm{~mm}$ lateral from the sagittal suture and $-4.0 \mathrm{~mm}$ ventral from the dural surface) (Paxinos and Watson 1998).
Microdialysis probes were constructed by inserting two fused silica tubes (30 and $35 \mathrm{~mm}$ long, $150 \mu \mathrm{m}$ outer diameter (o.d.); Polymicro Technologies Inc., Phoenix, AZ, USA) into a microdialysis fiber $(220 \mu \mathrm{m}$ o.d., AN69, Hospal, Bologna, Italy). The tube assembly was placed in a stainless steel cannula (22 gauge, $10 \mathrm{~mm}$ ) forming the shaft of the probe. Portions of the inlet and outlet tubes were individually placed inside polyethylene PE-10 tubing and glued for protection. The free end of the dialysis fiber was sealed, and $4 \mathrm{~mm}$ of the exposed length or $3 \mathrm{~mm}$ in the hippocampus was used for dialysis in the prefrontal cortex.

One day after surgery and probe implantation, the inlet of the dialysis probes was connected to a syringe pump (BAS, IN, USA), which delivered an artificial cerebrospinal fluid (aCSF) composed of (in $\mathrm{mM}$ ) $\mathrm{NaCl} 145, \mathrm{KCl} 2.7$, $\mathrm{MgCl}_{2} 1.0, \mathrm{CaCl}_{2} 1.2, \mathrm{pH}=7.4$, at a flow of $1.5 \mu \mathrm{l} / \mathrm{min}$. After $3 \mathrm{~h}$ of this washing period, when the extracellular level of zinc became stable, two baseline samples were collected every $40 \mathrm{~min}$ from freely moving animals. Next, the last doses of zinc hydroaspartate, imipramine or citalopram were i.p. injected into the animals and the consequent dialysate fractions were collected every $40 \mathrm{~min}$ for $160 \mathrm{~min}$. At the end of the experiment, the rats were killed and their brains were histologically examined to validate the correct probe placement.

\section{Extracellular zinc determination}

For detection of extracellular zinc concentration in brain microdialysates, we used differential pulse anodic stripping voltammetry (DP ASV, described in detail in Opoka et al. 2008).

Brain microdialysate samples were acidified with nitric acid immediately after collection by addition of $1 \mu \mathrm{HNO}_{3}$ (conc.) to each $30 \mu \mathrm{l}$ of the sample. The pretreatment, intended to destroy organic compounds (complexants and organic surfactants), followed the wet washing method used in the DP ASV determination of zinc ions in microdialysates. Then, samples were transferred directly into a miniature quartz tube and digested by UV irradiation for $2 \mathrm{~h}$. The quartz tubes were then left to cool to room temperature. Aliquots of $20 \mu \mathrm{l}$ of this solution were introduced into the electrochemical cell containing $2 \mathrm{ml}$ of the supporting electrolyte.

For all the voltammetric measurements, a multipurpose Electrochemical Analyzer M161 with and electrode stand M164 (both MTM-ANKO, Poland) was used. The stripping was performed in the differential pulse (DP) mode. As much as $2 \mathrm{ml}$ of $0.05 \mathrm{M} \mathrm{KNO}_{3}$ was added in the electrochemical cell as a blank and the solution was purged with argon of $99.995 \%$ purity for at least 5-7 min. The preconcentration step was carried out from the stirred solution for a period of $t_{\mathrm{acc}}=20 \mathrm{~s}$ at $E_{\mathrm{aac}}=-1.05 \mathrm{~V}$ versus $\mathrm{Ag} / \mathrm{AgCl}$, at a fresh 
mercury drop. After a rest period of $5 \mathrm{~s}$, the differential pulse voltammogram was recorded in the anodic direction from -1.05 to $-0.8 \mathrm{~V}$ with a potential scan rate of $25 \mathrm{mV} / \mathrm{s}$ and pulse amplitude of $-50 \mathrm{mV}$. The voltammogram for the blank solution demonstrates electrochemical cell and supports electrolyte purity. Then, $20 \mu \mathrm{l}$ of sample solution was added to the cell while maintaining an argon atmosphere over the solution and the differential pulse voltammograms were recorded. The quantitative determinations of zinc ions were performed using the standard additions method (three concentrations). Three curves were recorded and averaged for each of the concentrations. All of the samples were measured under the same conditions.

Data analysis

The results of the experiments were expressed as the means \pm SEM. The obtained data were evaluated by oneway or repeated measures of ANOVA followed by Dunnett's or Tukey's post hoc test, respectively, and the Student's $t$ test. Data were deemed significant when $P<0.05$.

\section{Results}

Microscopic analysis of synaptic zinc

Effect of chronic treatment with zinc hydroaspartate, imipramine and citalopram on the presynaptic zinc level in the rat prefrontal cortex

Densitometric analysis of the staining intensity of presynaptic (histochemically reactive, vesicular) zinc in the rat's prefrontal cortex showed a significant increase by zinc hydroaspartate or citalopram administration (Fig. 1a, b). ANOVA revealed $F(4,32)=4.475, P=0.0064$. The higher level $(50 \%$ of increase; $P<0.01)$ of zinc staining was observed after a treatment of zinc hydroaspartate at a dose of $65 \mathrm{mg} / \mathrm{kg}(\sim 11.3 \mathrm{mg}$ of zinc $/ \mathrm{kg})$. A small increase (by $34 \% ; P<0.05$ ) compared to that in the control rats was also recorded after the use of a lower dose of zinc hydroaspartate $(10 \mathrm{mg} / \mathrm{kg} ; \sim 1.8 \mathrm{mg}$ of zinc $/ \mathrm{kg})$. A similar effect (37\% of increase; $P<0.05$ ) was noted after citalopram administration. Moreover, imipramine treatment caused a statistically marginal increase (by $21 \%$, $P=0.057$ ) of staining intensity (Fig. 1a).

Effect of chronic treatment with zinc hydroaspartate, imipramine and citalopram on the presynaptic zinc level in the rat hippocampus

ANOVA revealed a significant effect of treatment on the presynaptic concentration in the whole hippocampus
[ANOVA: $F(3,22)=7.35, P<0.01]$. Post hoc testing revealed that repeated zinc hydroaspartate treatment at a dose of $10 \mathrm{mg} / \mathrm{kg} \quad(\sim 1.8 \mathrm{mg}$ of zinc $/ \mathrm{kg} ; \quad P<0.05)$ increased synaptic zinc staining in the whole hippocampus (Fig. 2).

Detailed measurement of relative optical density (ROD) performed in the Ammon's horn (CA) and dentate gyrus (DG) area showed a significant increase (by 19 and 24\%, respectively) of synaptic zinc staining; ANOVA: $F(3,22)=5.137, P=0.0104$ (CA area) $F(3,22)=9.227$, $P=0.008$ (DG area). This effect was stronger (with a $65 \%$ increase) after a higher dose of zinc $(\sim 11.3 \mathrm{mg}$ of zinc $/ \mathrm{kg})$ administration [Student's $t$ test: $t(9)=5.583, P=0.0025$ (CA area); $t(9)=2.837, \quad P=0.0364 \quad$ (DG area); $t(9)=5.310, \quad P=0.0032$ (whole hippocampus)]. No alterations in the distribution and intensity of zinc staining were observed after imipramine and citalopram treatment (Fig. 2).

Analysis of extracellular zinc concentration in brain microdialysate samples

The effect of chronic treatment with zinc hydroaspartate, imipramine and citalopram on the extracellular zinc concentration in the rat prefrontal cortex

Chronic imipramine administration at a dose of $20 \mathrm{mg} / \mathrm{kg}$ had no significant effect on the basal extracellular concentration of zinc in the prefrontal cortex (Table 1). However, such chronic treatment with zinc hydroaspartate $(65 \mathrm{mg} / \mathrm{kg} ; 11.3 \mathrm{mg}$ of zinc $/ \mathrm{kg})$ or citalopram $(20 \mathrm{mg} / \mathrm{kg})$ significantly (by $41 \% ; P<0.05$ or $36 \% ; P<0.05$, respectively) increased the extracellular zinc level when compared to the group treated with saline (Table 1). The maximal effect was seen $40 \mathrm{~min}(188 \%$ of basal level; $P<0.001)$ or between 80 (187\% of basal level; $P<0.01)$ and 120 min after the last doses of zinc hydroaspartate or citalopram administration, respectively (Fig. 3a; repeated measures ANOVA: $F(3,23)=10.893, \quad P=0.0002)$. Imipramine and citalopram, while zinc does not, increase the cumulative effect presented as an area under the curve (AUC, Fig. 3b; repeated measures ANOVA: $F(3,20)=$ 9.734, $P=0.0006)$.

The effect of chronic treatment with zinc hydroaspartate and citalopram on extracellular zinc concentration in the rat hippocampus

Chronic treatment with zinc hydroaspartate $(65 \mathrm{mg} / \mathrm{kg}$; $11.3 \mathrm{mg}$ of zinc $/ \mathrm{kg})$ or citalopram $(20 \mathrm{mg} / \mathrm{kg})$ significantly (by $38 \% ; P<0.01$ or $29 \% ; P<0.05$, respectively) increased the basal extracellular zinc level when compared with the group treated with saline (Table 1). The maximal 
Fig. 1 a The effect of chronic (14 days) treatment with zinc hydroaspartate, imipramine and citalopram on presynaptic zinc level in the rat prefrontal cortex measured by the selenium method. Values are expressed in relative optical density (ROD) as mean \pm SEM of $15-20$ sections from each of six rats per group. $* P<0.05$,

$* * P<0.01$ versus control (Dunnett's post hoc test). b Photomicrographs representing synaptic zinc staining in the prefrontal cortical sections from control ( $I$, III) and zinc hydroaspartate $(65 \mathrm{mg} / \mathrm{kg})$ treated rats $(I I, I V)$. Calibration bars in $I$ and $I I$, $500 \mu \mathrm{m} ; I I I$ and $I V, 200 \mu \mathrm{m}$
A

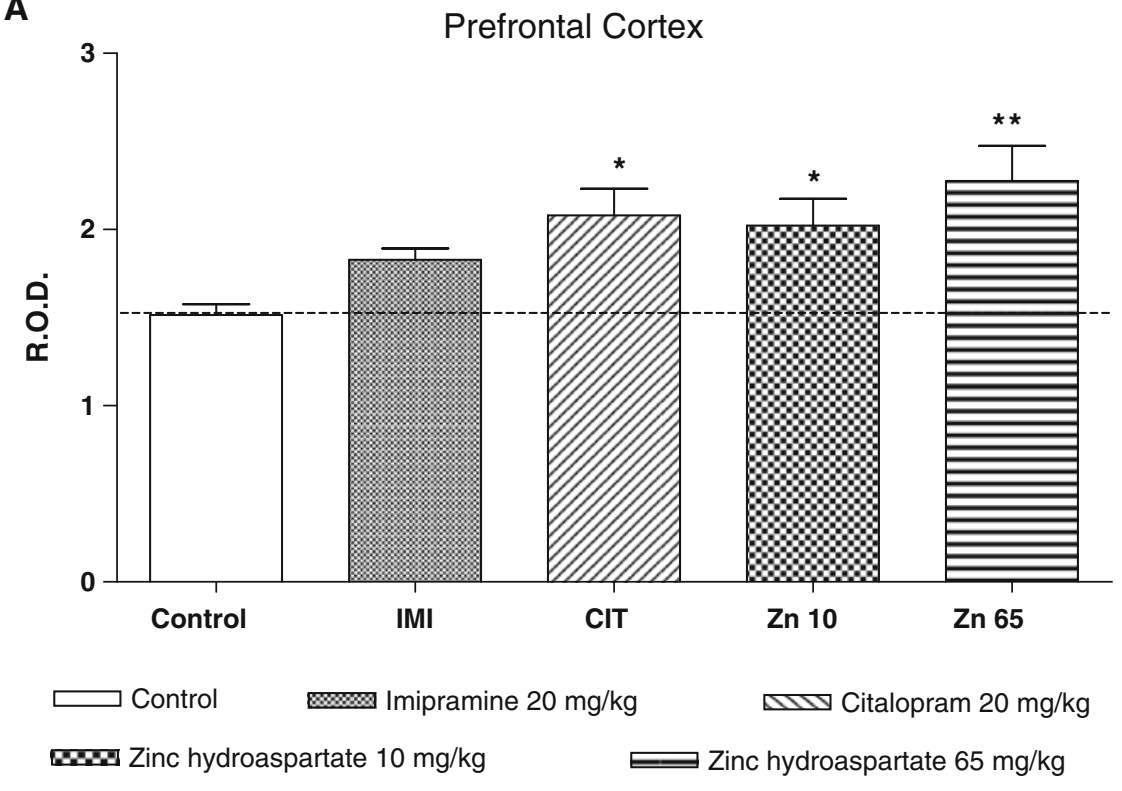

B
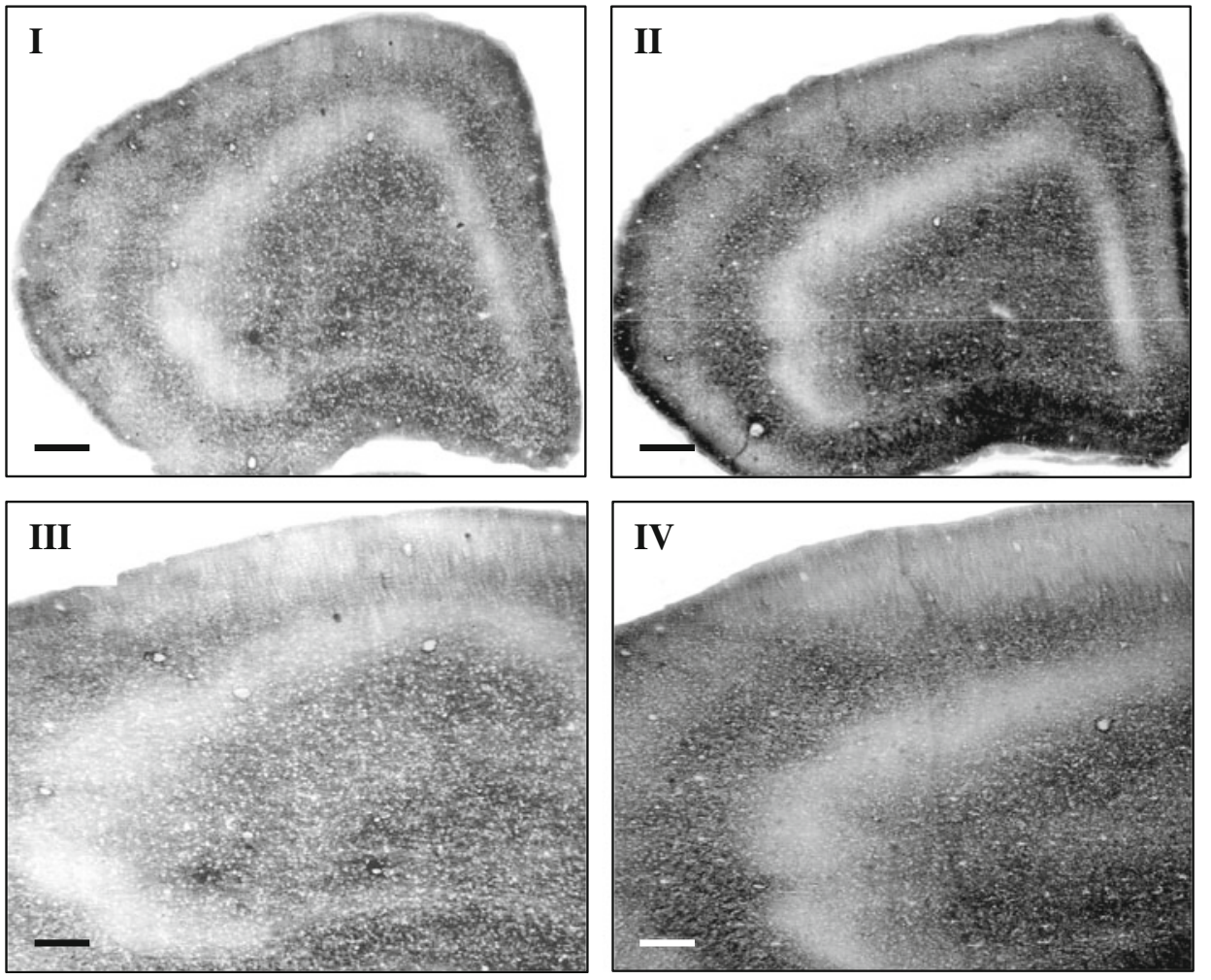

effect was seen at $40 \mathrm{~min}(190 \%$ of basal level; $P<0.05)$ after the final doses of zinc hydroaspartate (Fig. 4a). Citalopram induced no significant effect (Fig. 4a). Repeated measures ANOVA: $F(2,17)=5.546, P=0.0110$. None of the examined agents affected the area under the curve measurement (AUC, Fig. 4b).

\section{Discussion}

Zinc is co-released with glutamate upon activity of the presynaptic nerve terminals (Qian and Noebels 2005; Vogt et al. 2000). Chronic antidepressant treatment modifies the glutamatergic synapse, reducing its transmission by 

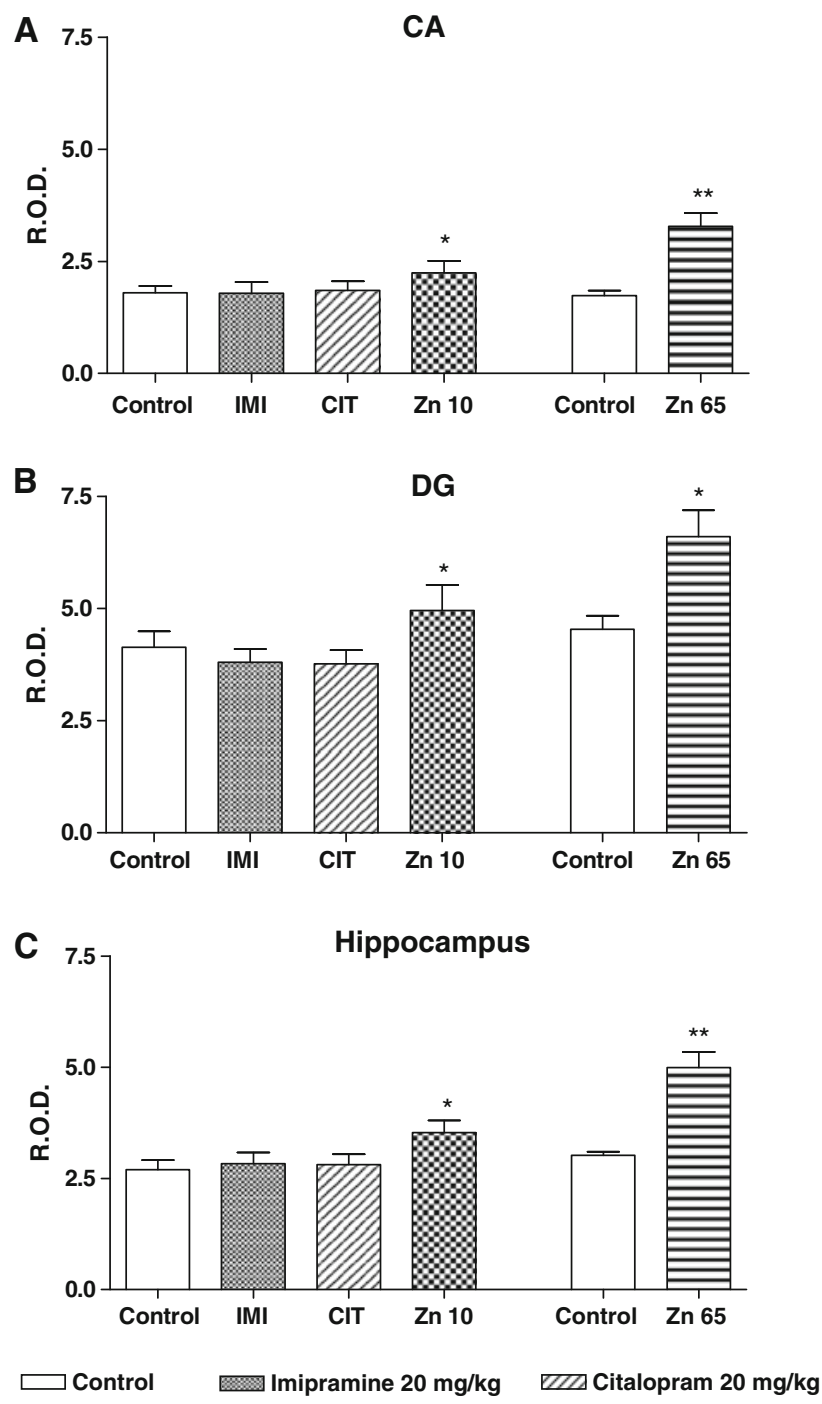

$\infty$ Zinc hydroaspartate $10 \mathrm{mg} / \mathrm{kg} \rightleftharpoons$ Zinc hydroaspartate $65 \mathrm{mg} / \mathrm{kg}$

Fig. 2 The effect of chronic (14 days) treatment with zinc hydroaspartate, imipramine and citalopram on the presynaptic zinc level in the rat hippocampus measured by the selenium method. Values are expressed in relative optical density (ROD) as mean \pm SEM of 15-20 sections from all of the six rats per group. a Ammon's horn $(C A)$ area, b dentate gyrus $(D G)$ area, $\mathbf{c}$ whole hippocampus. The results of zinc hydroaspartate at a dose of $65 \mathrm{mg} / \mathrm{kg}$ were calculated from the detailed data published previously (Szewczyk et al. 2006). $* P<0.05$, $* * P<0.01$ versus control (Dunnett's post hoc test or Student's $t$ test)

altering the glutamate NMDA receptors (Dybala et al. 2006; Mathie et al. 2006; Skolnick et al. 1996; Szewczyk et al. 2001). The opposite of these alterations is what has been proposed for depression (experimental models of depression) (Garcia et al. 2009; Kos et al. 2006; MachadoVieira et al. 2009; Nowak et al. 2003b; Popik et al. 2008; Zarate et al. 2006). Since the accumulated data demonstrate the antidepressant/adjunct role of zinc in preclinical and clinical reports (Nowak et al. 2003a; Siwek et al. 2009; see
Szewczyk et al. 2008 for review), one may suggest the involvement of "endogenous" zinc in the mechanism of antidepressant action. Actually, the presynaptic zinc (vesicular, histochemically reactive) level is enhanced by chronic electroconvulsive treatment (ECT) in the rat hippocampus (Gombos et al. 1999; Lamont et al. 2001; Vaidya et al. 1999). Moreover, our previous data demonstrated that repeated administration of zinc increases this particular pool of presynaptic zinc in the hippocampus (Szewczyk et al. 2006). However, such an effect is not demonstrated by chronic antidepressant drug treatment (Lamont et al. 2001). The total hippocampal zinc level is slightly increased by chronic treatment with imipramine or citalopram and the same treatments slightly reduce it in the neocortex of rats (Nowak and Schlegel-Zawadzka 1999). Chronic ECT, on the other hand, robustly increases the total zinc in both brain regions (Nowak and SchlegelZawadzka 1999).

The present data focused our attention to the frontal cortex. We demonstrated the increase in the presynaptic zinc pool induced by chronic treatment with zinc, citalopram and marginally by imipramine. Even more clearly, the effect was demonstrated in the extracellular zinc pool. All the examined treatments (zinc, citalopram, imipramine) produced an increase (with a different pattern of the dynamics of treatment-induced changes) in the extracellular zinc pool, measured at the time points as an area under the curve and/or basal level in the rat prefrontal cortex. The differences in the pattern of changes may be related to their differences in pharmacological mechanisms. Citalopram is a very potent and specific serotonin reuptake inhibitor, while imipramine is a serotonin/ noradrenaline reuptake inhibitor (Hyttel 1994). Thus, a strong serotonin enhancing mechanism may be important for the induction of an increase of presynaptic/extracellular zinc, especially in view of the recent study which indicates that the antidepressant-like activity of zinc depends on serotonin transmission (Szewczyk et al. 2009). A very rapid effect was noticed in the zinc treatment, a delayed but pronounced one for citalopram and a weak effect with imipramine. The basal level increased by zinc and citalopram treatment may represent an increased, yet stable, high concentration of zinc, which persistently interacts with different targets within the synapse. It should be noted that zinc is able to induce a transient increase in the extracellular zinc pool in the frontal cortex even by a single administration (Opoka et al. 2008).

It should be noticed that enhancement in the basal extracellular zinc in the frontal cortex, induced by chronic treatment with zinc and citalopram, is associated with an enhancement in presynaptic zinc assayed at the same time (24 $\mathrm{h}$ after the last administration). 
Table 1 Effect of chronic treatment with imipramine, citalopram or zinc on basal level of zinc in extracellular fluid measured in microdialysates by anodic stripping voltammetry

\begin{tabular}{lllll}
\hline Brain region & Control & Imipramine & Citalopram & Zinc \\
\hline Prefrontal cortex & $0.96 \pm 0.061$ & $1.16 \pm 0.087$ & $1.32 \pm 0.067^{*}$ & $1.35 \pm 0.126^{*}$ \\
Hippocampus & $0.95 \pm 0.063$ & n.d. & $1.23 \pm 0.039^{*}$ & $1.31 \pm 0.084^{* *}$ \\
\hline
\end{tabular}

Rats were treated with imipramine $(20 \mathrm{mg} / \mathrm{kg})$, citalopram $(20 \mathrm{mg} / \mathrm{kg})$ or zinc (hydroaspartate, $65 \mathrm{mg} / \mathrm{kg})$ once a day for 14 days. Results are expressed in $\mu \mathrm{M}$ as mean \pm SEM of four to five rats per group. ANOVA: $F(3,20)=5.827, P=0.0063$ (prefrontal cortex); $F(2,13)=7.985$, $P=0.0008$ (hippocampus)

n.d. not determined

* $P<0.05, * * P<0.01$ versus control (Dunnett's post hoc test)
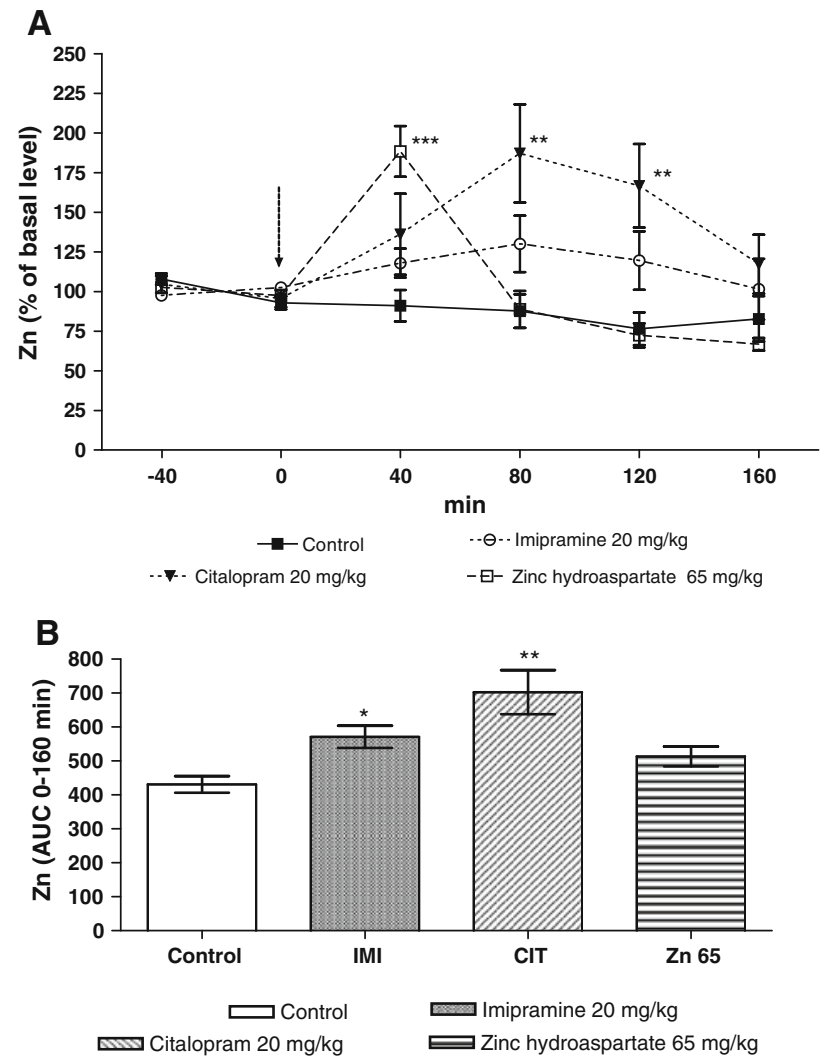

Fig. 3 The effect of chronic (14 days) treatment with zinc hydroaspatate, imipramine and citalopram on extracellular concentration of zinc in the rat prefrontal cortex measured in microdialysates by anodic stripping voltammetry. a Time course of the effect. The last administration is indicated by an arrow. b Area under the curve of 160 min collection time. Values are expressed as mean $\pm \mathrm{SEM}$, $n=4-5$ rats. $* P<0.05, * * P<0.01, * * * P<0.001$ versus basal level or control group (Tukey's post hoc test)

Chronic treatment with zinc and citalopram increased basal extracellular zinc in the hippocampus, while zinc alone produced a parallel enhancement of the presynaptic zinc pool in this structure (present data, Szewczyk et al. 2006). Thus, hippocampal presynaptic/extracellular homeostasis is regulated, similar to that in the cortex, only by zinc and not by citalopram treatment. The dynamics of the changes in the extracellular $\mathrm{Zn}$ induced by chronic
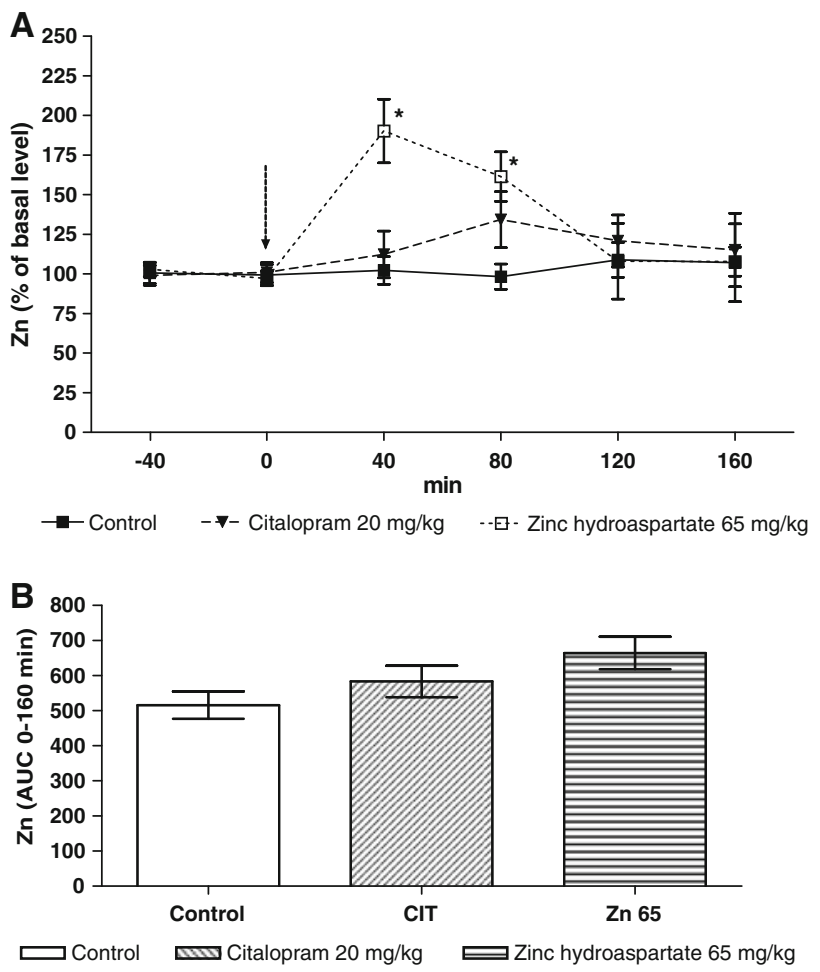

Fig. 4 The effect of chronic (14 days) treatment with zinc hydroaspartate and citalopram on extracellular concentration of zinc in the rat hippocampus measured in microdialysates by anodic stripping voltammetry. a Time course of the effect. The last administration is indicated by an arrow. b Area under the curve of 160 min collection time. Values are expressed as mean \pm SEM, $n=4-5$ rats. $* P<0.05$ versus basal level (Tukey's post hoc test)

treatment may represent a functionally operating synaptic zinc interacting with a variety of receptors and channels (Nakashima and Dyck 2009). Generally, citalopram's effect on presynaptic/extracellular zinc homeostasis is greater than the one by imipramine. It might be that a strong serotonergic component of the antidepressant activity of citalopram and zinc [recently demonstrated by (Cunha et al. 2008; Szewczyk et al. 2009)] has such an effect on presynaptic/extracellular $\mathrm{Zn}$, which warrants future studies. 
Recently, we demonstrated the involvement of the NMDA and AMPA glutamate receptors in the antidepressant-like activity of zinc in the FST (Poleszak et al. 2008; Szewczyk et al. 2010). The reduction in the immobility time induced by zinc is abolished by activation of NMDA receptor complex (by NMDA or D-serine) and by antagonism of the AMPA receptor (by NBQX) (Poleszak et al. 2008; Szewczyk et al. 2010). Moreover, the reduction in the NMDA/AMPA reactivity induced by chronic antidepressants and zinc treatments is demonstrated by an electrophysiological method (Bobula and Hess 2008). Our recent data indicated that chronic zinc treatment induced up-regulation of the 5-HT-1A and 5HT-2A serotonergic and down-regulation of the glycine/NMDA glutamatergic receptor, and enhances the BDNF mRNA and protein expressions, which are similar to that induced by conventional antidepressants (Cichy et al. 2009; Nowak et al. 2004; Paul and Skolnick 2003; Sowa-Kucma et al. 2008). Our results potentially indicate that an increase in the presynaptic/synaptic zinc concentration may be responsible (at least in part) for the induction of these adaptive alterations, which are involved in the antidepressant mechanism (Szewczyk et al. 2008). In view of the recent paper of Besser et al. (2009), synaptically released zinc may also activate the metabotropic zinc-sensing receptors $\mathrm{ZnR}$ (GPR39), specifically activated by zinc, besides the receptors for the well-known neurotransmitters [e.g. glutamate or serotonin (Nakashima and Dyck 2009)]. Accordingly, antidepressants induced the enhancement of synaptically released (extracellular) zinc via ZnR-induced enhancement of intracellular signal-regulated protein kinase1/2 (ERK1/2) and $\mathrm{Ca}^{2+} /$ calmodulin-activated protein kinase II (CaMKII), brain-derived neurotrophic factor (BDNF) cascade may activate anti-apoptotic/neurogenesis pathway(s) (Franco et al. 2008) involved in the antidepressant mechanism [e.g. see Covington et al. 2009; Duman and Monteggia 2006 for review]. Now, we can address the question of how chronic treatment with antidepressants increases the synaptic/extracellular zinc concentrations. We can speculate that antidepressants can move zinc from the protein-bound pool to the vesicle pool, then onto the extracellular, synaptic reactive pool, but this of course remains to be proved.

These data open exciting avenues to the hypothesis that the antidepressant mechanism relies on adaptive changes evoked by an antidepressant-induced increase of zinc in the synapse, and this notion should be examined in future studies.

Acknowledgments Preparation of this manuscript was supported by MNiSW Grant No. 2 P05A 017829 (2005-2008) and funds for statutory activity of the Institute of Pharmacology PAS, and Jagiellonian University Collegium Medicum, Krakow. The authors thank
Farmapol Sp. z o.o. and H. Lundbeck A/S for the generous gifts of zinc hydroaspartate and citalopram, respectively.

Open Access This article is distributed under the terms of the Creative Commons Attribution Noncommercial License which permits any noncommercial use, distribution, and reproduction in any medium, provided the original author(s) and source are credited.

\section{References}

Bancila V, Nikonenko I, Dunant Y, Bloc A (2004) Zinc inhibits glutamate release via activation of pre-synaptic $\mathrm{K}$ channels and reduces ischaemic damage in rat hippocampus. $\mathrm{J}$ Neurochem 90:1243-1250

Besser L, Chorin E, Sekler I, Silverman WF, Atkin S, Russell JT, Hershfinkel M (2009) Synaptically released zinc triggers metabotropic signaling via a zinc-sensing receptor in the hippocampus. J Neurosci 4:2890-2901

Bobula B, Hess G (2008) Antidepressant treatments-induced modifications of glutamatergic transmission in rat frontal cortex. Pharmacol Rep 60:865-871

Cichy A, Sowa-Kućma M, Legutko B, Pomierny-Chamioło L, Siwek A, Piotrowska A, Szewczyk B, Poleszak E, Pilc A, Nowak G (2009) Zinc-induced adaptive changes in NMDA/glutamatergic and serotonergic receptors. Pharmacol Rep 61:1184-1191

Cieslik K, Klen-Majewska B, Danilczuk Z, Wrobel A, Lupina T (2007) Influence of zinc supplementation on imipramine effect in a chronic unpredictable stress (CUS) model in rats. Pharmacol Rep 59:46-52

Corniola RS, Tassabehji NM, Hare J, Sharma G, Levenson CW (2008) Zinc deficiency impairs neuronal precursor cell proliferation and induces apoptosis via p53-mediated mechanisms. Brain Res 1237:52-61

Covington HE III, Maze I, La Plant QC, Vialou VF, Ohnishi YN, Berton O, Fass DM, Renthal W, Rush AJ III, Wu EY, Ghose S, Krishnan V, Russo SJ, Tamminga C, Haggarty SJ, Nestler EJ (2009) Antidepressant actions of histone deacetylase inhibitors. J Neurosci 29:11451-11460

Cunha MP, Machado DG, Bettio LE, Capra JC, Rodrigues AL (2008) Interaction of zinc with antidepressants in the tail suspension test. Prog Neuropsychopharmacol Biol Psychiatry 32:1913-1920

Czupryn A, Skangiel-Kramska J (2003) Switch time-point for rapid experience-dependent changes in zinc-containing circuits in the mouse barrel cortex. Brain Res Bull 61:385-391

Danscher G (1982) Exogenous selenium in the brain. A histochemical technique for light and electron microscopical localization of catalytic selenium bonds. Histochemistry 76:281-293

Drevets WC, Price JL, Furey ML (2008) Brain structural and functional abnormalities in mood disorders: implications for neurocircuitry models of depression. Brain Struct Funct 213:93-118

Duman RS, Monteggia LM (2006) A neurotrophic model for stressrelated mood disorders. Biol Psychiatry 59:1116-1127

Dybała M, Maciag D, Cichy A, Pomierny-Chamiolo L, Partyka A, Librowski T, Nowak G (2006) Medium supplementation with zinc enables detection of imipramine-induced adaptation in glycine/NMDA receptors labeled with [3H]L-689, 560. Pharmacol Rep 58:753-757

Franco JL, Posser T, Brocardo PS, Trevisan R, Uliano-Silva M, Gabilan NH, Santos AR, Lleal RB, Rodrigues AL, Farina M, Dafre AL (2008) Involvement of glutathione, ERK1/2 phosphorylation and BDNF expression in the antidepressant-like effect of zinc. Behav Brain Res 188:316-323 
Frederickson CJ, Bush AL (2001) Synaptically released zinc: physiological functions and pathological effects. Biometals 14:353-366

Frederickson CJ, Koh JY, Bush AL (2005) The neurobiology of zinc in health and disease. Nat Rev Neursci 6:449-462

Garcia LS, Comim CM, Valvassori SS, Réus GZ, Stertz L, Kapczinski F, Gavioli EC, Quevedo J (2009) Ketamine treatment reverses behavioral and physiological alterations induced by chronic mild stress in rats. Prog Neuropsychopharmacol Biol Psychiatry 33:450-455

Gombos Z, Spiller A, Cottrell GA, Racine RJ, McIntyre Burnham W (1999) Mossy fiber sprouting induced by repeated electroconvulsive shock seizures. Brain Res 844:28-33

Harrison NL, Gibbons SJ (1994) $\mathrm{Zn}^{2+}$ : an endogenous modulator of ligand- and voltage-gated ion channels. Neuropharmacology 33:935-952

Hyttel J (1994) Pharmacological characterization of selective serotonin reuptake inhibitors (SSRIs). Int Clin Psychopharmacol 9:19-26

Kos T, Legutko B, Danysz W, Samoriski G, Popik (2006) Enhancement of antidepressant-like effects but not brain-derived neurotrophic factor mRNA expression by the novel $N$-methyl-D-aspartate receptor antagonist neramexane in mice. J Pharmacol Exp Ther 318:1128-1136

Kroczka B, Zieba A, Dudek D, Pilc A, Nowak G (2000) Zinc exhibits an antidepressant-like effect in the forced swimming test in mice. Pol J Pharmacol 52:403-406

Kroczka B, Branski P, Pałucha A, Pilc A, Nowak G (2001) Antidepressant-like properties of zinc in rodent forced swim test. Brain Res Bull 55:297-300

Lamont SR, Paulls A, Stewart CA (2001) Repeated electroconvulsive stimulation, but not antidepressant drugs, induces mossy fibre sprouting in the rat hippocampus. Brain Res 893:53-58

Lorenzetti V, Allen NB, Fornito A, Yücel M (2009) Structural brain abnormalities in major depressive disorder: a selective review of recent MRI studies. J Affect Disord 117:1-17

Machado-Vieira R, Salvadore G, Diazgranados N, Zarate CA Jr (2009) Ketamine and the next generation of antidepressants with a rapid onset of action. Pharmacol Ther 123:143-150

Maes M, D'Haese PC, Scharpe S, D'Hondt (1994) Hypozincemia in depression. J Affect Disord 31:135-140

Maes M, Vandoolaeghe E, Neels H, Demedts P, Wauters A, Meltzer HY, Altamura C (1997) Lower serum zinc in major depression is a sensitive marker of treatment resistance and of the immune/ inflammatory response in that illness. Biol Psychiatry 42:349-358

Maes M, De Vos N, Demedts P, Wauters A (1999) Lower serum zinc in major depression in relation to changes in serum acute phase proteins. J Affect Disord 56:189-194

Mathie A, Sutton GL, Clarke CE, Veale EL (2006) Zinc and copper pharmacological probes and endogenous modulators of neuronal excitability. Pharmacol Ther 111:567-583

McLoughlin IJ, Hodge SJ (1990) Zinc in depressive disorder. Acta Psychiatr Scand 82:451-453

Nakashima AS, Dyck RH (2009) Zinc and cortical plasticity. Brain Res Rev 59:347-373

Nowak G, Schlegel-Zawadzka M (1999) Alterations in serum and brain trace element levels after antidepressant treatment: part I. Zinc Biol Trace Elem Res 67:85-92

Nowak G, Zięba A, Dudek D, Krośniak M, Szymaczek M, SchlegelZawadzka M (1999) Serum trace elements in animal models and human depression. Part I. Zinc, Hum Psychopharmacol Clin Exp 14:83-86

Nowak G, Siwek M, Dudek D, Zieba A, Pilc A (2003a) Effect of zinc supplementation on antidepressant therapy in unipolar depression: a preliminary placebo-controlled study. Pol J Pharmacol 55:1143-1147
Nowak G, Szewczyk B, Sadlik K, Piekoszewski W, Trela F, Florek E, Pilc A (2003b) Reduced potency of zinc to interact with NMDA receptors in hippocampal tissue of suicide victims. Pol J Pharmacol 55:455-459

Nowak G, Szewczyk B, Wieronska JM, Branski P, Palucha A, Pilc A, Sadlik K, Piekoszewski W (2003c) Antidepressant-like effects of acute and chronic treatment with zinc in forced swim test and olfactory bulbectomy model in rats. Brain Res Bull 61:159-164

Nowak G, Legutko B, Szewczyk B, Papp M, Sanak M, Pilc A (2004) Zinc treatment induces cortical brain-derived neurotrophic factor gene expression. Eur J Pharmacol 492:57-59

Opoka W, Sowa-Kućma M, Kowalska M, Baś B, Gołembiowska K, Nowak G (2008) Intraperitoneal zinc administration increases extracellular zinc in the rat prefrontal cortex. J Physiol Pharmacol 59:477-487

Paul IA, Skolnick P (2003) Glutamate and depression: clinical and preclinical studies. Ann NY Acad Sci 1003:250-272

Paxinos G, Watson C (1998) The rat brain in stereotaxic coordinates. Academic Press, San Diego

Poleszak E, Szewczyk B, Wlaź A, Fidecka S, Wlaź P, Pilc A, Nowak $\mathrm{G}$ (2008) D-serine, a selective glycine/ $N$-methyl-D-aspartate receptor agonist, antagonizes the antidepressant-like effects of magnesium and zinc in mice. Pharmacol Rep 60:996-1000

Popik P, Kos T, Sowa-Kućma M, Nowak G (2008) Lack of persistent effects of ketamine in rodent models of depression. Psychopharmacology (Berl) 198:421-430

Qian J, Noebels JL (2005) Visualization of transmitter release with zinc fluorescence detection at the mouse hippocampal mossy fibre synapse. J Physiol 566:747-758

Rajkowska G, Miguel-Hidalgo JJ (2007) Gliogenesis and glial pathology in depression. CNS Neurol Disord Drug Targets 6:219-233

Rosa AO, Lin J, Calixto JB, Santos AR, Rodrigues AL (2003) Involvement of NMDA receptors and L-arginine-nitric oxide pathway in the antidepressant-like effects of zinc in mice. Beh Brain Res 144:87-93

Schlegel-Zawadzka M, Zieba A, Dudek D, Krosniak M, Szymaczek M, Nowak G (2000) Effect of depression and of antidepressant therapy on serum zinc levels-a preliminary clinical study. In: Roussel AM, Anderson RA, Favrier AE (eds) Trace elements in man and animals 10. Kluwer Academic Plenum Press, New York, pp 607-610

Siwek M, Dudek D, Paul IA, Sowa-Kućma M, Zięba A, Popik P, Pilc A, Nowak G (2009) Zinc supplementation augments efficacy of imipramine in treatment-resistant patients: a double-blind, placebo-controlled study. J Affect Disord 118:187-195

Skolnick P, Layer RT, Popik P, Nowak G, Paul IA, Trullas R (1996) Adaptation of $N$-methyl-D-aspartate (NMDA) receptors following antidepressant treatment: implications for the pharmacotherapy of depression. Pharmacopsychiatry 29:23-26

Slomianka L (1992) Neurons of origin of zinc-containing pathways and the distribution of zinc-containing boutons in the hippocampal region of the rat. Neuroscience 48:325-352

Smart TG, Xie X, Krishek BJ (1994) Modulation of inhibitory and excitatory amino acid receptor ion channels by zinc. Prog Neurobiol 42:393-441

Sowa-Kućma M, Legutko B, Szewczyk B, Novak K, Znojek P, Poleszak E, Papp M, Pilc A, Nowak G (2008) Antidepressantlike activity of zinc: further behavioral and molecular evidence. J Neural Transm 115:1621-1628

Szewczyk B, Kata R, Nowak G (2001) Rise in zinc affinity for the NMDA receptor evoked by chronic imipramine is speciesspecific. Pol J Pharmacol 53:641-645

Szewczyk B, Branski P, Wieronska JM, Palucha A, Pilc A, Nowak G (2002) Interaction of zinc with antidepressants in the forced swimming test in mice. Pol J Pharmacol 54:681-685 
Szewczyk G, Sowa M, Czupryn A, Wieronska JM, Branski P, Sadlik K, Opoka W, Piekoszowski W, Smialowska M, SkangielKramska J, Pilc A, Nowak G (2006) Increase in synaptic hippocampal zinc concentration following chronic but not acute zinc treatment in rats. Brain Res 1090:69-75

Szewczyk B, Poleszak E, Sowa-Kućma M, Siwek M, Dudek D, Ryszewska-Pokraśniewicz B, Radziwoń-Zaleska M, Opoka W, Czekaj J, Pilc A, Nowak G (2008) Antidepressant activity of zinc and magnesium in view of the current hypotheses of antidepressant action. Pharmacol Rep 60:588-599

Szewczyk B, Poleszak E, Wlaź P, Wróbel A, Blicharska E, Cichy A, Dybała M, Siwek A, Pomierny-Chamioło L, Piotrowska A, Brański P, Pilc A, Nowak G (2009) The involvement of serotonergic system in the antidepressant effect of zinc in the forced swim test. Prog Neuropsychopharmacol Biol Psychiatry 33:323-329

Szewczyk B, Poleszak E, Sowa-Kućma M, Wróbel A, Slotwiński S, Listos J, Wlaż, Cichy A, Siwek A, Dybała M, Gołembiowska K, Pilc A, Nowak G (2010) Involvement of NMDA and AMPA receptors in the antidepressant-like activity of zinc in the forced swim test. Amino Acids. doi:10.1007/s00726009-0412-y
Takeda A (2000) Movement of zinc and its functional significance in the brain. Brain Res Rev 34:137-148

Takeda A, Minami A, Seki Y, Oku N (2003) Inhibitory function of zinc against excitation of hippocampal glutamatergic neurons. Epilepsy Res 57:169-174

Tassabehji NM, Corniola RS, Alshingiti A, Levenson CW (2008) Zinc deficiency induces depression-like symptoms in adult rats. Physiol Behav 95:365-369

Vaidya VA, Siuciak JA, Du F, Duman RS (1999) Hippocampal mossy fiber sprouting induced by chronic electroconvulsive seizures. Neuroscience 89:157-166

Vogt K, Mellor J, Tong G, Nicoll R (2000) The actions of synaptically released zinc at hippocampal mossy fiber synapses. Neuron 26:187-196

Whittle N, Lubec G, Singewald N (2009) Zinc deficiency induces enhancement depression-like bahviour and altered limbic activation reversed by antidepressant treatment in mice. Amino Acids 36:147-158

Zarate CA Jr, Singh JB, Carlson PJ, Brutsche NE, Ameli R, Luckenbaugh DA, Charney DS, Manji HK (2006) A randomized trial of an $N$-methyl-D-aspartate antagonist in treatment-resistant major depression. Arch Gen Psychiatry 63:856-864 